\author{
Çocuk ve Gelişim Dergisi (ÇG-D) \\ Journal of Child and Development (J-CAD) \\ Cilt 2 (2019) Say1 4, 44-57
}

Araştırma Makalesi

\title{
Engelli Çocuklarda Oyun İle İlgili Yapılan Lisansüstü Tezlerdeki Eğilimler
}

\section{Tendencies In The Graduate Thesis Written About The Play In Disabled Children}

Prof. Dr. Figen GÜRSOY, Ankara Üniversitesi, Sağlık Bilimleri Fakültesi, Çocuk Gelişimi Bölümü, gursoy.f@gmail.com

Dr. Öğr. Üyesi Fatih AYDOĞDU, Erzincan Binali Yıldırım Üniversitesi, Sağlık Hizmetleri Meslek Yüksekokulu, Çocuk Bakımı ve Gençlik Hizmetleri Bölümü, faydogdu1985@gmail.com

Dr. Öğr. Üyesi Burçin AYSU, Ankara Yıldırım Beyazıt Üniversitesi, Sağlık Bilimleri Fakültesi, Çocuk Gelişimi Bölümü, burcinaysu@windowslive.com

Prof. Dr. Neriman ARAL, , Ankara Üniversitesi, Sağlık Bilimleri Fakültesi, Çocuk Gelişimi Bölümü, aralneriman@gmail.com

Öz

Bu çalş̧manın amacı, 1997-2018 yılları arasında engelli çocuklarda oyun üzerine yapılan lisansüstü tezlerin çeşitli değişkenler açısından incelenmesidir. Engelli çocuklarda oyun alanında hazırlanan lisansüstü tezler; yıllara, üniversitelere, enstitülere, engel türüne, araştırma türüne ve araştırma modeline göre değerlendirilmiştir. Araştırmanın çalışma grubunu, 1997-2018 yılları arasında YÖK Tez Dokümantasyon Merkezine kayıtlı elektronik ortamda ulaşılabilen engelli çocuklarda oyun üzerine hazırlanmış 37 yüksek lisans, 9 doktora tezi ve 1 uzmanlık tezi olmak üzere toplam 47 tez oluşturmaktadır. Araştırma verileri, nitel araştırma veri toplama yöntemlerinden doküman incelemesi tekniği kullanılarak toplanmıştır. Araştırma verileri, betimsel analiz yöntemiyle çözümlenmiş, alt problemler ölçüt alınarak değerlendirilmiş, tablolaştırlarak sayısal olarak ifade edilmiştir. Çalışma sonucunda; engelli çocuklarda oyun alanında yapılan tezlerin en çok2016, 2017 ve 2018 yllarında hazırlandığı, engelli çocuklarda oyun alanında yazılan tezlerde özellikle 2013 yllından sonra artış yaşandığı görülmüştür. Engelli çocuklarda oyun alanında yapılan lisansüstü tezlerin en fazla Anadolu ve Gazi Üniversitesinde hazırlandığ1 belirlenmiştir. Engel türlerinden en çok otizmli çocuklarla ilgili çalışmaların yapıldığı saptanmıştır. Çalışmaların çoğunluğunun deneysel desenle yürütüldüğü ve daha çok nicel yöntemle yürütüldüğü görülmüştür. Engelli çocuklarda oyun alanında son yıllarda lisansüstü tezlerde artış yaşanmasına rağmen, ortopedik engelli, dikkat eksikliği ve hiperaktivite ve işitme engelli çocuklarda oyun alanında yapılan çalışmaların sınırlı sayılda olduğu belirlenmişstir.

Anahtar Kelimeler: Engelli, oyun, lisansüstü tezler 


\begin{abstract}
The aim of this study is to examine the graduate thesis written between 1997-2018 on play in the disabled children in terms of various variables. The graduate thesis written about the play in the disabled children were evaluated according to their years, universities, graduate schools, types of disability, types of research and research model. The study group of the study consisted of 47 theses; 37 master thesis, 9 doctoral dissertations and 1 specialty thesis which were prepared on play in the disabled children, were written between 1997-2018, were registered in Council of Higher Education Thesis Documentation Center and were electronically accessible. The data of the study were obtained using one of the qualitative research data collection methods; the document review technique. Further, the data of the study were analyzed via descriptive analysis method, they were evaluated by taking the subproblems as criterion, they were tabularized and given numerically. As a result of the study; it was found that the theses about theplay in the disables children were written at most in 2016, 2017 and 2018 and an increase was seen in those thesis especially after 2013. Furthermore, it was determined that the graduate thesis written about the play in the disabled children were prepared at most in Anadolu and Gazi Universities. It was also concluded that the studies about the autistic children were carried out at most in terms of thetypes of disability. Also, it was found tha tmost of the studies were done with experimental design and the qualitative method was used more. It was determined that although there has been an increase in the studies about the play in the disabled children recently, the these written about the play in the orthopedically handicapped children, children with attention deficit, hyperactive children and children with impaired hearing were in limited number.
\end{abstract}

Keywords: Disabled, play, graduatethesis

\title{
Giriş
}

Genel bir tanımla oyun, rahatlama, fazla enerjinin atılması, uygulama yapma, isteklerin yerine getirilmesi, zevk alma ve bir öğrenme şeklidir. İnsan davranışlarının bütünü dikkate alındığında çocukların oynadıkları oyunların çoğunlukla yaşam deneyimlerinden oluştuğu görülmektedir (Aksoy, 2018). Bu nedenle çocukların gelişimi için oyunun önemli olduğu söylenebilir. Oyun çocukluktaki en tipik aktivitedir; oyun çocukların büyümek, anlamak, sosyalleşmek ve kişiliğini geliştirmek için ihtiyaç duydukları şeydir. Oyun ile çocuklar deneme yapmakta, icat etmekte, hatalar yapmakta, egzersiz yapmakta, şaka yapmakta, taklit etmekte, birbirlerini kızdırmakta, risk almakta ve böylece istedikleri zaman faydalanacakları bir dünya yaratmaktadırlar (Besio ve Stancheva-Popkostadınova, 2018).

Özellikle sahip oldukları dezavantajlar nedeniyle engelli çocukların gelişiminin desteklenmesinde oyun daha önemli bir yere sahiptir. Oyun, engelli çocukların doğumdan sonraki süreçte engelli olmayan diğer çocuklarla aynı gelişim özelliklerini göstermeseler de içsel enerjisinin boşaltılması, genel gelişiminin sağlanması ve deneyim kazanılması açısından önemlidir. Engelli çocuklar özelinde de düşünüldüğünde, bu çocukların kendilerini daha rahat ifade edebilmeleri, sorun ve gereksinimlerinin belirlenmesi ve bunların çözümüne yönelik ne gibi beklentilerinin olduğunun anlaşılması konularında oyundan yararlanılması önemlidir (Aykara, 2017). Oyun ile engelli çocuklar, sosyal becerileri uygulamak için çeşitli sosyal ortamlar edinir. Bu ortamlar onlar için bir öğrenme ortamıdır. Oyun ortamında engelli çocuklar 
akranlarını gözlemler, etkileşime girer ve böylece öğrenme olanağı edinir (Brown ve Bergen, 2002). Oyun yoluyla başkalarını ve çevreyi keşfetmeyi, iletişim kurmayı ve onlarla etkileşmeyi öğrenmek, engelli çocuklar için sorunlu olabilir, ancak ebeveyn desteği ile çocuklar oyun etkinlikleri sırasında başarılı bir şekilde öğrenebilir ve etkileşime girebilir (Childress, 2011).

Engelli çocukların oyunla ilgili deneyimi açısından bilimsel araştırmalar önemli bir konumdadır. Yapılan araştırmalar incelendiğinde okul öncesinde oyun ve kaynaştırma (Metin, 2013) ile ilgili yapılan lisansüstü tezlerin incelendiği araştırmaların bulunmasına rağmen; engelli çocuklarda oyun ile ilgili çalışmaların eğiliminin belirlendiği araştırmaya rastlanmamıstır. Engelli çocuklarda oyun ile ilgili araştırmaların incelenmesi sonucu elde edilen bilgilerle engelli çocuk ve oyun olgusuna dair araştırmaların yönünün belirleneceği düşünülmektedir. Bu düşünceden hareketle bu çalsşmada Türkiye'de engelli çocuklarla ile ilgili yapılmış lisansüstü tezlerin incelenmesi amaçlanmıştır.

\section{Yöntem}

Bu çalışmada Türkiye'de engelli çocuklarla ile ilgili yapılmış lisansüstü tezlerin incelenmesi amaçlanmıştır.

\section{Araştırmanın Modeli}

1997-2018 y1lları arasında engelli çocuklarda oyunla ilgili yapılan lisansüstü tezleri yıl, üniversite, enstitü, engel türü, araştırma türü ve araştırma modeli açısından incelemeyi amaçlayan bu çalışmada nitel araştırma yöntemlerinden doküman analizi kullanılmıştır. Doküman analizi, bir araştırma problemi hakkında belirli zaman dilimi içerisinde üretilen dokümanlar ya da ilgili konuda birden fazla kaynak tarafindan ve değişik aralıklarla üretilmiş dokümanların belirli bir zaman dilimine bağlı olarak incelenmesini içermektedir (Yıldırım ve Şimşek, 2011).

\section{Çalışma Grubu-Evren Örneklem}

Araştırmanın çalışma grubunu, 1997-2018 yılları arasında YÖK Tez Dokümantasyon Merkezine kayıtlı elektronik ortamda ulaşılabilen engelli çocuklarda oyun üzerine hazırlanmış 37 yüksek lisans, 9 doktora tezi ve 1 uzmanlık tezi olmak üzere toplam 47 tez oluşturmaktadır.

\section{Verilerin Toplanması ve Analizi}

Araştırma verileri, nitel araştırma veri toplama yöntemlerinden doküman incelemesi tekniği kullanılarak toplanmıştır. Doküman incelemesi, araştırılması hedeflenen olgu ya da olgular hakkında bilgi içeren yazılı materyallerin analizini kapsamaktadır. Bu tür araştırmalarda, araştırmacı, ihtiyacı olan veriyi, gözlem veya görüşme yapmaya gerek kalmadan tek başına bir veri toplama yöntemi olarak kullanabilir (Yıldırım ve Şimşek, 2011). Veriler, YÖK'e bağlı ulusal tez merkezi sayfasında yapılan taramalar sonucunda toplanmıştır. Sayfada tarama terimi bölümüne “oyun, zihinsel engel, görme bozukluğu, işitme bozukluğu, ortopedik engel, dikkat eksikliği, otizm” kavramları yazılarak arama yapılmıştır. Tezler pdf formatında bilgisayar ortamına aktarılmıştır.

Araştırmada ulaşılan lisansüstü tezleri incelemek üzere araştırmacılar tarafindan "Tez İnceleme Formu" geliştirilmiştir. Geliştirilen bu formda tezlerin adını, yılını, türünü, hazırlandığı üniversiteyi ve enstitüyü, 
engel türünü, araştırma türünü ve araştırma modelini kapsayan bilgiler yer almıştır. Elde edilen veriler inceleme formunda belirtilen ilgili bölümler altında kodlanmıştır. Bir araştırmacı tarafından yapılan kodlamalar, diğer bir araştırmacı tarafindan da kontrol edilmiştir. Kodlamalar arasında bulunan farklılıklar düzeltilerek araştırmacılar arasında uzlaşma sağlanmış ve bulgulara son şekli verilmiştir. Araştırma verileri, betimsel analiz yöntemiyle çözümlenmiş, alt problemler ölçüt alınarak değerlendirilmiş, tablolaştırılarak sayısal olarak ifade edilmiştir.

\section{Bulgular ve Tartışma}

$\mathrm{Bu}$ bölümde, engelli çocuklarda oyun alanında yapılan lisansüstü tezlerin; yıllara, üniversitelere, enstitülere, engel türüne, araştırma türüne ve araştırma modelinegöre dağılımlarına yer verilmiştir.

\section{1997-2018 yılları arasında engelli çocuklarda oyun ile ilgili yapılan lisansüstü tezlerin yıllara göre dağılımı}

Engelli çocuklarda oyun ile ilgili yapılan lisansüstü tezlerin yıllara göre dağılımı Tablo 1'de verilmiştir.

Tablo 1: Lisansüstü tezlerin yıllara göre dağılımı

\begin{tabular}{lcccc}
\hline & \multicolumn{2}{c}{ Tez Türü } & \multirow{2}{*}{ Toplam } \\
\cline { 2 - 5 } Y1llar & Yüksek Lisans & Doktora Tezi & Tipta Uzmanlik & 1 \\
\hline 1997 & 1 & - & - & 1 \\
\hline 2000 & 1 & - & - & 1 \\
\hline 2001 & 1 & - & - & 1 \\
\hline 2005 & 1 & - & - & 1 \\
\hline 2006 & 1 & - & - & 1 \\
\hline 2010 & 1 & - & - & 2 \\
\hline 2011 & 2 & - & - & 1 \\
\hline 2012 & 1 & - & - & 3 \\
\hline 2013 & 2 & 1 & - & 3 \\
\hline 2014 & 3 & - & - & 5 \\
\hline 2015 & 4 & 1 & 1 & 9 \\
\hline 2016 & 5 & 3 & - & 9 \\
\hline 2017 & 7 & 2 & - & 9 \\
\hline 2018 & 7 & 2 & 1 & 47 \\
\hline Toplam & 37 & 9 & & \\
\hline
\end{tabular}

Tablo 1 incelendiğinde engelli çocuklarda oyun ile ilgili en çok 2016 ( $f=9), 2017$ ( $f=9)$ ve 2018 ( $f=9$ ) yıllarında hazırlandığı görülmektedir. Tez türüne bakıldığında ise hem yüksek lisans hem de doktora tezlerinin aynı yıllarda daha çok olduğu tespit edilmiştir. 1997-2018 yıllanı arasında 1 uzmanlık tezi olduğu belirlenmiştir. Engelli çocuklarda oyun alanında yazılan tezlerde özellikle 2013 yılından sonra artış yaşandığı söylenebilir. Bu sonuç engelli çocukların oyun yoluyla gelişimi açısından önemli görülmektedir. Engelli çocuklarda oyun alanındaki çalışmaların artış göstermesi, engelli çocukların oyun yoluyla gelişiminin desteklenmesi açısından önemli çalışmaların yapılmasını sağlayabilecektir. Engelli çocukların iletişim kurmaları, boş zaman etkinliklerine katılmaları, akranları ile sosyalleşmeleri ve eğitimlerine devam edebilmeleri için oyun bir yöntem olarak kullanılabilir. Böylece engelli çocukların topluma uyum göstermesi de sağlanabilir (Çiftçi ve Aydın, 2017). 


\subsection{7-2018 yılları arasında engelli çocuklarda oyun ile ilgili yapılan lisansüstü tezlerin üniversitelere göre dağılımı}

Engelli çocuklarda oyun ile ilgili yapılan lisansüstü tezlerin üniversitelere göre dağılımı Tablo 2'de verilmiştir.

Tablo 2: Lisansüstü tezlerin üniversitelere göre dağılımı

\begin{tabular}{|c|c|c|c|c|}
\hline Üniversite & $\begin{array}{c}\text { Yüksek Lisans } \\
\text { Tezi }\end{array}$ & $\begin{array}{c}\text { Tez Türü } \\
\text { Doktora Tezi }\end{array}$ & $\begin{array}{c}\text { Tipta } \\
\text { Uzmanlık }\end{array}$ & Toplam \\
\hline Anadolu Üniversitesi & 7 & - & - & 7 \\
\hline Gazi Üniversitesi & 5 & 1 & - & 6 \\
\hline Ankara Üniversitesi & 3 & - & - & 3 \\
\hline Orta Doğu Teknik Üniversitesi & 2 & 1 & - & 3 \\
\hline Abant İzzet Baysal Üniversitesi & 1 & 1 & - & 2 \\
\hline Sakarya Üniversitesi & 1 & 1 & - & 2 \\
\hline Marmara Üniversitesi & 2 & - & - & 2 \\
\hline Hacettepe Üniversitesi & 1 & 1 & - & 2 \\
\hline Üsküdar Üniversitesi & 2 & - & - & 2 \\
\hline Atatürk Üniversitesi & 1 & 1 & - & 2 \\
\hline İstanbul Medipol Üniversitesi & 1 & 1 & - & 2 \\
\hline İzmir Yüksek Teknoloji Üniversitesi & 1 & - & - & 1 \\
\hline Selçuk Üniversitesi & 1 & - & - & 1 \\
\hline Firat Üniversitesi & 1 & - & - & 1 \\
\hline İstanbul Şehir Üniversitesi & 1 & - & - & 1 \\
\hline Sabanc1 Üniversitesi & 1 & - & - & 1 \\
\hline Mehmet Akif Ersoy Üniversitesi & 1 & - & - & 1 \\
\hline Akdeniz Üniversitesi & - & 1 & - & 1 \\
\hline Necmeddin Erbakan Üniversitesi & 1 & - & - & 1 \\
\hline Harran Üniversitesi & - & - & 1 & 1 \\
\hline İstanbul Üniversitesi & - & 1 & - & 1 \\
\hline Beykent Üniversitesi & 1 & - & - & 1 \\
\hline Hitit Üniversitesi & 1 & - & - & 1 \\
\hline Karadeniz Teknik Üniversitesi & 1 & - & - & 1 \\
\hline Trakya Üniversitesi & 1 & - & - & 1 \\
\hline Toplam & 37 & 9 & 1 & 47 \\
\hline
\end{tabular}

Tablo 2 incelendiğinde, 25 üniversitede lisansüstü çalışmanın yapıldığı görülmektedir. Çalışmaların yapıldığı üniversitelere bakıldığında en çok Anadolu Üniversitesi (f=7) ve Gazi Üniversitesinde (f=6) yürütüldüğü, yüksek lisans çalışmalarının da aynı üniversitelerde daha çok yapıldığı, doktora çalışmalarının olduğu üniversitelerde ise dağılımın eşit olduğu görülmektedir. Tipta uzmanlık çalışmasının da sadece bir üniversitede yayınlandığı tespit edilmiştir. Tezlerin üniversitelere göre dağılımına bakıldığında 25 üniversitede çalışmaların yapılması önemli bir sonuç olarak görülmektedir. Bununla birlikte konu alanında lisansüstü programlara sahip diğer üniversitelerde oyun alanında çalışmaların yapılmadığ1 görülmektedir. Engelli çocuklarda oyunun farklı üniversite ve akademisyenler tarafindan bilimsel nitelikli lisansüstü tez çalışmalarında ele alınması, oyunun engelli çocukların gelişimi açısından daha etkili bir yöntem olarak kullanılmasını sağlayabilecektir. Oyun ile engelli çocukların fiziksel farkındalık artması ve bedensel yeterliklerinin gelişmesini (Ulutaşdemir, 2007) ve sosyal yetkinliklerinin artmasını (Vute, 2009) sağlayabilir. 


\subsection{7-2018 yılları arasında engelli çocuklarda oyun ile ilgili yapılan lisansüstü tezlerin enstitülere göre dağılımı}

Engelli çocuklarda oyun ile ilgili yapılan lisansüstü tezlerin enstitülere göre dağılımı Tablo 3 ’te verilmiştir.

Tablo 3: Lisansüstü tezlerin enstitülere göre dağılımı

\begin{tabular}{lcccc}
\hline \multirow{2}{*}{ Enstitü } & \multicolumn{3}{c}{ Tez Türü } & \\
& $\begin{array}{l}\text { Yüksek Lisans } \\
\text { Tezi }\end{array}$ & Doktora Tezi & Toplam \\
Eğitim Bilimleri Enstitüsü & 15 & 4 & 19 \\
Sosyal Bilimler Enstitüsü & 12 & - & 12 \\
Sağlık Bilimleri Enstitüsü & 6 & 3 & 10 \\
Enformatik Enstitüsü & 2 & - & 2 \\
Fen Bilimleri Enstitüsü & 1 & 1 & 2 \\
Mühendislik ve Fen Bilimleri Enstitüsü & 1 & 1 & 2 \\
Toplam & 37 & 9 & 46 \\
\hline
\end{tabular}

Tablo 3'e göre engelli çocuklarda oyun ile ilgili yapılan tezlerin 6 farklı enstitüde yayınlandığı tespit edilmiştir. Tezlerin en çok yayınlandığı enstitünün Eğitim Bilimleri Enstitüsü (f=19) söylenebilir. Tıpta Uzmanlık çalışması ise Tıp Fakültesinde yayınlanmıştır. Tezlerin farklı enstitülerde yapılmış olması, engelli çocuklarda oyun ile ilgili çalışmaların farklı boyutlarıyla ele alındığını göstermektedir. Engelli çocuklarda oyun ile ilgili çalışmaların Eğitim Bilimleri ve Sosyal Bilimler Enstitülerinde daha çok yayınlanması, oyunu eğitsel ve sosyal yönüyle etkin kılma çabasından kaynaklanıyor olabilir. Çocukların akranlarıyla olan iletişimlerini ve becerilerini, akranlarıyla olan sosyal uyumlarını ve çatışmalarını ve davranış sorunlarını ortaya koymak açısından oyun önemli bir araçtır (Aslan, 2017; Leff, Costigan ve Power, 2004). Özellikle gelişim alanlarında bazı gecikmeler yaşayan engelli çocukların içinde yaşadıkları sosyal çevreyle iletişim kurmada ve çevrelerindeki çeşitli uyarıcılara tepki vermede güçlük çekmesi (Metin, Şahin ve Şanlı, 1999), oyunun engelli çocukların gelişimlerini destekleme sürecinde kullanılmasının önemli olduğu söylenebilir.

\subsection{7-2018 yılları arasında engelli çocuklarda oyun ile ilgili yapılan lisansüstü tezlerin engel türüne göre dağ1lımı}

Engelli çocuklarda oyun ile ilgili yapılan lisansüstü tezlerin engel türüne göre dağılımı Tablo 4'te verilmiştir.

Tablo 4: Lisansüstü tezlerin engel türüne göre dağılımı

\begin{tabular}{ll}
\hline \multicolumn{1}{c}{ Engel TürüToplam } & 17 \\
Otizm & 9 \\
Zihinsel engel & 6 \\
Zihinsel engel-serebralpalsi & 5 \\
Isşitme & 5 \\
Görme & 4 \\
Dikkat eksikliği ve hiperaktivite Ortopedik & 1 \\
& 47 \\
Toplam & \\
\hline
\end{tabular}


Tablo 4 incelendiğinde engelli çocuklarda oyun alanında 7 farklı engel türüyle ilgili çalışmaların yapıldığı görülmektedir. En çok otizm ( $\mathrm{f}=17$ ) ve zihinsel engel/serebralpalsi ( $\mathrm{f}=15)$ ile ilgili çalışmanın yapıldığı söylenebilir. Birçok engel türüne özgü çalışmalar yapılmasına rağmen ortopedik engel ile ilgili oyun alanında yapılan çalışmaların yetersiz olduğu söylenebilir. Oyun, ortopedik engelli çocukların hareket fonksiyonlarının ve motor becerilerinin gelişimi açısından önemlidir. Kanmaz (2017) yaptı̆̆ araştırmada, hareketli oyun eğitim programı sonrasında ortopedik engelli çocukların kaba motor gelişimlerinde ve özellikle denge sağlama, el ve kollarını kullanma ve sıçrama becerilerinde olumlu etkiler belirlemiştir.

\subsection{7-2018 yılları arasında engelli çocuklarda oyun ile ilgili yapılan lisansüstü tezlerin araştırma türüne göre dağılımı}

Engelli çocuklarda oyun ile ilgili yapılan lisansüstü tezlerin araştırma türüne göre dağılımı Tablo 5’te verilmiştir.

Tablo 5: Lisansüstü tezlerin araştırma türüne göre dağılımı

\begin{tabular}{lc}
\hline Araştırma Türü & Toplam \\
Nicel & 21 \\
Nitel & 19 \\
Karma & 7 \\
Toplam & 47 \\
\hline
\end{tabular}

Tablo 5 incelendiğinde engelli çocuklarda oyun alanında yapılan lisansüstü tezlerin 21'inin nicel, 19'unun nitel ve 7’sinin karma araştırma türünde yürütüldügüü görülmektedir. Karma desenli araştırmaların nicel ve nitel araştırma türüne göre daha az olduğu görülmektedir. Karma desenli çalışmaların engelli çocuklarda oyunun farklı yönleriyle ve bütünsel olarak ortaya konulacağı düşünülmektedir. Karma yöntem araştırmaları, çok yönlü potansiyele sahip olması ve derinlemesine analiz gerektiren disiplinlerarası araştırmaların yapılmasına olanak tanıması yönleriyle son zamanlarda daha çok tercih edilen bir araştırma türü olarak karşımıza çıkmaktadır (Fırat, Yurdakul ve Ersoy, 2014; Tashakkori ve Teddlie, 2003).

\section{1997-2018 yılları arasında engelli çocuklarda oyun ile ilgili yapılan lisansüstü tezlerin araştırma modeline göre dağılımı}

Engelli çocuklarda oyun ile ilgili yapılan lisansüstü tezlerin araştırma modeline göre dağılımı Tablo 6'da verilmiştir.

Tablo 6: Lisansüstü tezlerin araştırma modeline göre dağlımı

\begin{tabular}{ll}
\hline Araştırma modeli & Toplam \\
Deneysel & 37 \\
Tarama-betimsel & 12 \\
Toplam & 47 \\
\hline
\end{tabular}


Tablo 6 incelendiğinde engelli çocuklarda oyun ile ilgili yapılan lisansüstü tezlerin 37'sinin deneysel desende yürütüldüğü ve 12'sinin tarama-betimsel modelle gerçekleştiği görülmektedir. Deneysel desende çalışmaların çoğunlukta olması önemli bir sonuç olarak görülmektedir. Engelli çocuklarda oyun alanında yapılan çalışmalarda, engelli çocuklar üzerinde müdahale programlarının uygulanması, hem uygulama yapılan çocuklar üzerinde etki bırakabilecek, hem uygulayıcılara rehber bir program niteliği kazandıracak hem de sonradan yapilacak müdahale çalışmalarına kaynak oluşturabilecektir. Yaman (2019), oyunun özel gereksinimli çocukların sosyal gelişimleri üzerinde etkili olduğunu, Movahedazarhouligh(2018) ise, oyunun engelli çocukların boş zamanlarını etkili kullanmada ve hareket becerilerinin gelişiminde etkili olabileceğini vurgulamıştır.

\section{Sonuç ve Öneriler}

Araştırma kapsamında 1997-2018 yılları arasında YÖK Tez Dokümantasyon Merkezine kayıtlı elektronik ortamda ulaşılabilen engelli çocuklarda oyun üzerine hazırlanmış tezler incelenmiştir. Bu kapsamda konu ile ilgili 37 yüksek lisans, 9 doktora tezi ve 1 uzmanlık tezi olmak üzere toplam 47 tez olduğu görülmüştür. Tezler, yıl, üniversite, enstitü, engel türü, araştırma türü ve araştırma modeli gibi değişkenler açısından incelenmiştir. Tezlerin özellikle 2013 yllından sonra artış gösterdiği, 25 farklı üniversite ve 6 farklı enstitüde çalışmaların yapıldığı, daha çok otizmli ve zihinsel engelli çocukları konu alan çalışmalara yer verildiği, daha çok nicel araştırma türünde ve deneysel modelde araştırmaların yürütüldüğ̈ tespit edilmiştir.

Türkiye'de engelli çocuklarla ile ilgili yapılmış lisansüstü tezlerin incelenmesi amacıyla gerçekleştirilen bu araştırmadan elde edilen sonuçlara göre şunlar önerilebilir:

- Doktora tez danışmanları, konu ile ilgili çalışmaların yürütülmesi için öğrencilerini yönlendirebilir.

- Lisansüstü programı olan diğer üniversitelerde konu ile ilgili çalışmalar yapılabilir.

- Araştırmacılar ortopedik engel türüyle ilgili deneysel çalışmalar yapabilir.

- Farklı engel türlerinin de dahil edildiği lisansüstü çalışmalar incelenebilir.

- Engelli çocuklarda sanat, hareket, müzik gibi alanlarda yapılan lisansüstü çalışmalar araştırılabilir.

\section{Kaynakça}

Aksoy, A.B. (2018). Erken çocukluk döneminde oyun ve oyunun gelişimsel katkıları. Erken çocukluk döneminde oyun (Ed. Aksoy, A. B.,\& Çiftçi, H. D.). Pegem Atıf İndeksi, 2-17.

Aslan, Ö. M. (2017). 36-71 Aylık Çocuklar İçin Oyun Davranış Ölçeğinin Geliştirilmesi: Geçerlik ve Güvenirlik Çalışması. Kastamonu Eğitim Dergisi, 25(3), 897-910. 
Aykara, A. (2017) Çocuk Merkezli Oyun Terapisinin Engelli Çocuklara Yönelik Sosyal Hizmet Uygulamaları Açısından Önemi. Toplum ve Sosyal Hizmet, 28(1), 169-186.

Besio, S.,Stancheva-Popkostadınova, V. (2018). Supporting Play ForTheSake Of Play In Children With Disabilities. Supportİng Play For The Sake Of Play In Children With Disabilities, 7.

Brown, M.,\&Bergen, D. (2002). Play and social interaction of children with disabilities at learning/activitycenters in an inclusive preschool. Journal of Research in Childhood Education, 17(1), 26-37.

Childress, D. C. (2011). Play behaviors of parents and their young children with disabilities. Topics in Early Childhood Special Education, 31(2), 112-120.

Çiftçi, E. K.,\& Aydın, D. (2017). Engelli Çocuk ve Oyun. Türkiye Klinikleri PediatricNursing-Special Topics, 3(3), 176-184.

Fırat, M., Yurdakul, I. K., \& Ersoy, A. (2014). Bir eğitim teknolojisi araştırmasına dayalı olarak karma yöntem araştırması deneyimi. Eğitimde Nitel Araştırmalar Dergisi, 2(1), 64-85.

Kanmaz, T. (2017). Hareketli Oyun Eğitim Programının Okul Öncesi Kaynaştırma Eğitimi Alan Ortopedik Engelli Çocukların Kaba Motor Becerilerine Etkisinin İncelenmesi. (Yayımlanmamış Yüksek Lisans Tezi), G.Ü. Eğitim Bilimleri Enstitüsü:Ankara.

Kaytez, N.,Durualp, E. (2014). Türkiye'de okul öncesinde oyun ile ilgili yapılan lisansüstü tezlerin incelenmesi. Uluslararası Türk Eğitim Bilimleri Dergisi , (2) , 110-122.

Leff, S. S.,Costigan, T. ve Power, T. J. (2004). Using participatory-actionresearchtodevelop a playgroundbasedprevention program. Journal of School Psychology, 42, 3-21.

Metin, Ş. (2013). Türkiye'de Okul öncesinde kaynaştırmaya ilişkin yapılan çalışmaların incelenmesi. Bayburt Eğitim Fakültesi Dergisi, 8 (1) , 146-172.

Metin, N., Şahin, S. ve Şanlı, E. (1999). Okul öncesi düzeyde ve dört-dokuz yaş grubundaki zihinsel engelli çocukların tercih ettikleri oyun köşeleri ve oynadıkları oyun tiplerinin incelenmesi. Ankara Üniversitesi Eğitim Bilimleri Fakültesi Özel Eğitim Dergisi, 2(3), 14-24.

Movahedazarhouligh, S. (2018). Teaching play skils to children with disabilities: Research-based interventions and practices. EarlyChildhood Education Journal, 46(6), 587-599.

Tashakkori, A. \&Teddlie, C. (2003). The past and future of mixed methods research: From data triangulation to mixed model designs. In A. Tashakkori ve C. Teddlie (Eds.). Handbook of Mixed Methods in Social and Behavioral Research, (pp. 671-701). Thousand Oaks, CA: Sage. 
Ulutaşdemir, N. (2007). Engelli çocuklarda iletişim ve oyunun önemi. Fırat Sağlık Hizmetleri Dergisi, 2(5), 36-51.

Yaman, D. (2019). Oyunun Özel Gereksinimli Çocukların Sosyal Gelişimine Etkisi Hakkındaki Öğretmen Görüşleri. Yüksek Lisans Tezi. Yakın Doğu Üniversitesi Eğitim Bilimleri Enstitüsü, Lefkoşa.

Yıldırım, A. ve Şimşek H. (2011). Sosyal bilimlerde nitel araştırma yöntemleri. Ankara: Seçkin Yayıncılık.

EK1

Ağlamış, C. E. (2016). Serebralpalsi: Oyun eğitiminin fonksiyona etkisi. Akdeniz Üniversitesi. Sağlık Bilimleri Enstitüsü. Doktora Tezi

Aktürk Ablan, H. (2013). Görme engelli çocuklar için oyuncak tasarımı ölçütlerinin geliştirilmesi: Yeni bir oyun seti tasarımı. İzmir İleri Teknoloji Üniversitesi. Mühendislik ve Fen Bilimleri Enstitüsü. Yüksek Lisans Tezi

Altun, G. P. (2015). Serebralpalsi'li çocuklarda sanal gerçeklik oyunlarının üst ekstremite fonksiyonları üzerine etkisi. Marmara Üniversitesi. Sağllk Bilimleri Enstitüsü. Yüksek Lisans Tezi

Aslan, B. (2018). Bir çocuk psikiyatrisi kliniğine başvuran hastalarda dikkat eksikliği ve hiperaktivite bozukluğu, klinik görünüm, sosyodemografik özellikler, eştanı ve bilgisayar oyunları bağımlılığının incelenmesi. Üsküdar Üniversitesi. Sosyal Bilimler Enstitüsü. Yüksek Lisans Tezi

Avcıl, E. (2017). Serebralpalsili olgularda video bazlı oyunların üst ekstremite fonksiyonlarına etkinliğinin araştırılması. İstanbul Medipol Üniversitesi. Sağlık Bilimleri Enstitüsü. Yüksek Lisans Tezi

Bayam, A. (2017). 2-6 yaş arasındaki otizm spektrum bozukluğu olan çocuklara uygulanan oyun seansının sosyal beceri ve dil gelişiminde yol açtı̆̆ı değişimin incelenmesi. Beykent Üniversitesi. Sosyal Bilimler Enstitüsü. Yüksek Lisans Tezi

Bekeç, M. (2018). Deneyimsel oyun terapisinin dikkat eksikliği ve hiperaktivite bozukluğu tanısı olan 611 yaş arasındaki çocukların duygu ve davranışları üzerindeki etkisinin incelenmesi. Üsküdar Üniversitesi. Sosyal Bilimler Enstitüsü. Yüksek Lisans Tezi

Besler, F. (2015). Anneler tarafindan sunulan video modelle öğretimin otizmli çocuklara oyun becerisi öğretmedeki etkililiği. Anadolu Üniversitesi. Sosyal Bilimler Enstitüsü. Yüksek Lisans Tezi

Beyazoğlu, G. (2014). Oyun ve su terapilerinin otizm tanısı almış bir çocukta gözlenen davranış bozukluklarının azaltılması üzerindeki etkilerinin incelenmesi. Karadeniz Teknik Üniversitesi. Eğitim Bilimleri Enstitüsü. Yüksek Lisans Tezi 
Boyraz, E. (2017). Zihinsel engelli çocuklara kurallı oyun öğretiminde aşamalı yardımla öğretim yönteminin etkililiğinin incelenmesi. Necmettin Erbakan Üniversitesi. Eğitim Bilimleri Enstitüsü. Yüksek Lisans Tezi

Ciddi, P.(2018). Serebralpalsili çocuklarda video temelli oyun tedavisinin tedavi yoğunluğuna etkisi. Hacettepe Üniversitesi. Sağlık Bilimleri Enstitüsü. Doktora Tezi

Coşkun, N. (1997). Okul öncesi çağda işitme engelli çocuğu olan normal işiten bir annenin grup oyunu esnasında kullandığı stratejilerin incelenmesi. Anadolu Üniversitesi. Sosyal Bilimler Enstitüsü. Yüksek Lisans Tezi

Çakıc1, A. (2018). Dikkat eksikliği ve hiperaktivite bozukluğu olan çocukların yönetsel işlevler ile görsel algılarına bazı oyunların etkisi. Atatürk Üniversitesi. Eğitim Bilimleri Enstitüsü. Doktora Tezi

Çattık, M. (2016). Küçük grup içinde akıllı tahtada aşamalı yardımla öğretimin otizm spektrum bozukluğu olan çocukların dijital oyun ve gözleyerek öğrenme becerileri üzerindeki etkililiği. Anadolu Üniversitesi. Sosyal Bilimler Enstitüsü. Yüksek Lisans Tezi

Dalgın Eyiip, Ö. (2011). Bilgisayar destekli etkinlik çizelgeleriyle sunulan öğretimin otizm spektrum bozukluğu gösteren çocukların çizelge izleme ve rol oyun becerilerini öğrenmedeki etkileri. Anadolu Üniversitesi. Eğitim Bilimleri Enstitüsü. Yüksek Lisans Tezi

Demir, M. (2016). Yazıca zenginleştirilmiş oyunun anaokuluna devam eden zihinsel engelli öğrencilerin yazı farkındalığı becerilerine etkisi. Gazi Üniversitesi. Eğitim Bilimleri Enstitüsü. Yüksek Lisans Tezi

Ekin, C. Ç. (2017). Zihinsel engelli çocuklara hayat bilgisi kavramlarının öğretiminde akıllı oyuncaklar. Ortadoğu Teknik Üniversitesi. Fen Bilimleri Enstitüsü. Doktora Tezi

Elieyioğlu, S. (2014). 10-15 yaş işitme engelli öğrencilerde sportif eğitsel oyunların fiziksel gelişimlerine etkisinin araştırılması. Atatürk Üniversitesi. Sağlık Bilimleri Enstitüsü. Yüksek Lisans Tezi

Er, Ö. (2018). Otizmli çocuklarda hareket eğitimi ve eğitsel oyun ile yaşam kalitesi ilişkisinin incelenmesi. Hitit Üniversitesi. Sağllk Bilimleri Enstitüsü. Yüksek Lisans Tezi

Ergin, G. (2017). Otizm spektrum bozukluğu olan çocukların hayali oyun davranışlarının çeşitlendirilmesinde ipucunun giderek arttrrılmasıyla öğretimin etkililiği. Anadolu Üniversitesi. Eğitim Bilimleri Enstitüsü. Yüksek Lisans Tezi

Işık, M. (2016). Zihinsel engelli çocuklarda hemsball oyun becerilerinin motor yeterlik sonuçlarına etkisi. Gazi Üniversitesi. Sağlık Bilimleri Enstitüsü. Doktora Tezi 
Kanmaz, T. (2017). Hareketli oyun eğitim programının okul öncesi kaynaştırma eğitimi alan ortopedik engelli çocukların kaba motor becerilerine etkisinin incelenmesi. Gazi Üniversitesi. Eğitim Bilimleri Enstitüsü. Yüksek Lisans Tezi

Kaptan, S. (2018). Otizm spektrum bozukluğu olan çocuklara video modelle öğretim yöntemiyle sosyodramatik oyun öğretimi. Abant İzzet Baysal Üniversitesi. Eğitim Bilimleri Enstitüsü Yüksek Lisans Tezi

Kars, S. (2018). 4-6 yaş arası otizm spektrum bozukluğu olan çocukların oyun beceri ve davranışlarının incelenmesi. Hacettepe Üniversitesi. Sağlık Bilimleri Enstitüsü. Yüksek Lisans Tezi

Kılıçoğlu, M. (2006). Anasınıfı, hazırlık ve ilköğretim birinci sınıflarda okuyan görme engelli öğrencilerin oyunlarının değerlendirilmesi: Karşılaştırmalı bir araştırma. Selçuk Üniversitesi. Sosyal Bilimler Enstitüsü. Yüksek Lisans Tezi

Konya, O. (2014). Hareket algilama sistemleri ile oynanabilen oyunlar aracilı̆̆ıla görme engelli bireylerin görüş etkinliklerinin geliştirilmesi. Ortadoğu teknik Üniversitesi. Enformatik Enstitüsü. Yüksek Lisans Tezi

Kurnaz, E. (2016). Otizm spektrum bozukluğu olan çocuklara video oyunu oynama becerisinin öğretiminde video ile kendine model olmanın etkililiğinin belirlenmesi. Anadolu Üniversitesi. Sosyal Bilimler Enstitüsü. Yüksek Lisans Tezi

Nazırzadeh, M. J. (2015). Zihinsel engelli çocuklar için temel yaşam becerileri öğretmek amaçlı bedensel hareket oyunları geliştirilmesi. Enformatik Enstitüsü. Yüksek Lisans Tezi

Nasırı, N. (2017). Konuşma bozukluğu ve işitme engelli çocuklar için ciddi bir oyun. istanbul şehir Üniversitesi. Fen Bilimleri Enstitüsü. Yüksek Lisans Tezi

Öncül, N. (2015). Otizm spektrum bozukluğu olan çocuklara sembolik oyunların küçük grupla öğretiminde canlı modelle ve video modelle öğretimin karşılaştırılması. Abant İzzet Baysal Üniversitesi. Eğitim bilimleri Enstitüsü. Doktora Tezi

Özenmiş, P. (2000). Zihinsel engelli olan ve olmayan çocukların nesne ile oyun davranışlarının karşılaştırmalı olarak incelenmesi. Ankara Üniversitesi. Sosyal Bilimler Enstitüsü. Yüksek Lisans Tezi

Papatğa, E. (2012). Otizmli çocukların oyun becerileri ile davranış ve sosyal beceri özelliklerinin karşılaştırılması. Trakya Üniversitesi. Sosyal Bilimler Enstitüsü. Yüksek Lisans Tezi

Pehlevan, Ş. 2010). Zihinsel engelli çocukların sosyalleşmelerinde Türk halk oyunlarının etkisinin araştırılması. Sakarya Üniversitesi. Sosyal Bilimler Enstitüsü. Yüksek Lisans Tezi 
Püren, İ. (2017). İşitme engelli milli takım futbolcularına uygulanan dar alan oyunlarının akut fizyolojik etkilerini ve algılanan zorluk düzeyleri açısından karşılaştırılması. Fırat Üniversitesi. Sağlık Bilimleri Enstitüsü. Yüksek Lisans Tezi

Sani Bozkurt, S. (2011). Otizmli çocuklara rol oyun becerilerinin öğretiminde akran ve yetişkin modelin kullanıldığı video modelin etkililiği ve verimliliği. Anadolu Üniversitesi. Eğitim Bilimleri Enstitüsü. Yüksek Lisans Tezi

Sarar Boyraz, D. (2016). Otizmli çocuklara kurallı oyunların öğretiminde aşamalı yardımla öğretim yönteminin etkililiği. Marmara Üniversitesi. Eğitim Bilimleri Enstitüsü. Yüksek Lisans Tezi

Serimer, Z. (2005). Beceri gelişimine yönelik oyunların görme engellilere uyarlanması. Gazi Üniversitesi. Eğitim Bilimleri Enstitüsü. Yüksek Lisans Tezi

Sinan, S. (2001). İşitme engelli bir çocuğun annesi ile oynadığ1 oyunlarda kullandığı ifadelerin anlamsal ilişkiler bakımından incelenmesi. Ankara Üniversitesi. Eğitim Bilimleri Enstitüsü. Yüksek Lisans Tezi

Şahin, R. (2013). Okul öncesi dönem görme engelli çocukların oyun çeşitlilik ve karmaşıklık düzeyini artırmada genişletme tekniğinin etkililiği. Gazi Üniversitesi. Eğitim Bilimleri Enstitüsü. Yüksek Lisans Tezi

Şakalar, A. (2016). Serebralpalsili çocuklarda interaktif video oyunlarının fonksiyonel etkinliğinin ve radyolojik progresyonun difüzyon tensör görüntüleme (DTI) ile karşılaştırılması. Harran Üniversitesi. Tip Fakültesi . Tipta Uzmanlık Tezi

Şengül, Y. (2018). Otizm spektrum bozukluğu olan çocukların nesneli oyun ve taklit becerilerinin alıcı ve ifade edici dil sözcük dağarcığı ile ilişkisi. Ankara Üniversitesi. Eğitim Bilimleri Enstitüsü Yüksek Lisans Tezi

Tarakcı, D. (2013). SerebralPalsili çocuklarda video bazlı denge oyunlarının etkinliği. İstanbul Medipol Üniversitesi. Sağlık Bilimleri Enstitüsü. Doktora Tezi

Uncular, D. (2018). Otizm spektrum bozukluğu risk değerlendirmesine yönelik robotik oyuncak ve kullanıcı arayüzü tasarımı. Sabancı Üniversitesi. Sosyal Bilimler Enstitüsü. Yüksek Lisans Tezi

Üzüm, S. (2016). Oyun ve fiziki etkinlikler, beden eğitimi ve spor dersleri kapsamında yer alan öğretim programları kazanımlarının Türkiye'deki görme engelliler ilk ve ortaokullarında gerçekleşebilme durumlarına ilişkin öğretmen görüşleri. Gazi Üniversitesi. Eğitim Bilimleri Enstitüsü. Yüksek Lisans Tezi 
Yaman, T. (2015). Beden eğitimi ve oyunun hafif düzey zihinsel engelli bireylerin sosyal beceri kazanımları üzerine etkisinin araştırılması. Mehmet Akif Ersoy Üniversitesi. Eğitim Bilimleri Enstitüsü. Yüksek Lisans Tezi

Yılmaz, A. (2017). Beden eğitimi ve oyun uygulamalarının hafif düzey zihinsel engelli çocukların fiziksel uygunluk, eğitsel performans ve okul sosyal davranışları üzerine etkisi. Sakarya Üniversitesi. Eğitim Bilimleri Enstitüsü. Doktora Tezi

Zorlu, A. (2016). Yönlendirici olmayan oyun terapisinin dikkat eksikliği hiperaktivite bozukluğu belirtili çocukların duygu ve davranışları üzerindeki etkisinin incelenmesi. İstanbul Üniversitesi. Eğitim Bilimleri Enstitüsü. Doktora Tezi 